\title{
Cidade, migração e alteridade
}

Normando Jorge de Albuquerque Melo

Resumo: O presente artigo vincula-se a pesquisa que realizei em função do meu mestrado em antropologia, na qual procurei observar um processo "astucioso" de reapropriação/reinvenção do espaço pelo/para o uso do trabalho, que resultava na emergência de "agricultores" e "hortas" nos interstícios do complexo viário "Contorno do Recife", na capital pernambucana. Através da "história de vida" pude reconstruir as trajetórias dos agricultores e do espaço por eles ocupado. O contexto da ocupação é marcado pela migração, que se revelou como uma importante "força" no processo de reinvenção/reapropriação observado. Verificada a intimidade entre migração e cidade, apresento aqui algumas notas sobre a problemática desta relação, simultaneamente antagônica e complementar, a partir de um terceiro tema: a(s) alteridade(s).

Palavras-chave: cidade, astúcias, migração, alteridade, Recife.

\section{City, migration e other}

Abstract: This article is linked with the research that I did at my Master of Antropology, in which I sought to observe an "astute" process of reappropriation/reinvention of space by/for the use of the work, that resulted in the emergence of the "agriculturists" and the "vegetable garden" in the interstices of the complex road "Contorno do Recife", at the capital of Pernambuco. Through "life history" I could rebuild the trajectories of the agriculturists and of the space used by them. The context of the occupation is marked by the migration, that was showed up as an important "force" in the observed process of reinvention/reappropriation. Verified the intimacy between migration and city, I present here some notes about the problematic of this relation, simultaneously antagonistic and complementary, from one third subject: the other.

Key-words: city, astuteness, migration, other, Recife.

* Doutorando em Sociologia pelo PPGSA / UFRJ, atuando na área de Cidadania, Conflito Social e Violência Urbana. E-Mail: normandojorge@gmail.com

Latitude, Vol. 2, nº 1, pp.26-42, 2008. 


\section{Introdução}

O presente artigo é resultado de uma tentativa de aproximação da experiência de 7 agricultores que "abriram hortas" nos interstícios do "Contorno do Recife", na órbita da CEASA - Central de Abastecimento Sociedade Anônima - na capital pernambucana (MELO, 2007). Este foi o meu referencial empírico e o ponto de partida da minha pesquisa de dissertação para o mestrado em antropologia (PPGA/UFPE).

Quando eu anunciava que desenvolvia uma pesquisa com os agricultores da órbita da CEASA, perguntavam-me se era sobre "ruralidades". Para estas pessoas, esse era o "atrativo científico" do local. O meu interesse, no entanto, eram as práticas desviacionistas do uso dos espaços e as tensões delas decorrentes. "Dar a ver", em primeiro plano, a cidade como uma importante e complexa experiência de (des)humanidade e a condição do humano nela implicado.

O que me (co) moveu, pois, a realizar a pesquisa com aqueles agricultores foi o processo de reapropriação/reinvenção do espaço pelo/para o uso do trabalho, que eu identificava naquele local, e para o qual concorriam as "astúcias". Assumindo o desafio proposto por (CERTEAU, 1994), procurei investigar esses procedimentos, suas bases, efeitos e possibilidades.

Por meio da "história de vida" pude reconstruir as trajetórias dos agricultores e do espaço por eles ocupado. O contexto da ocupação é marcado pela migração, que se revelou como uma importante "força" no processo de reinvenção/reapropriação observado. Verificada a intimidade entre migração e cidade, apresento aqui algumas notas sobre a problemática desta relação, simultaneamente antagônica e complementar, a partir de um terceiro tema: a(s) alteridade(s).

\section{Narrações de um processo astucioso}

Apesar de gravitarem em torno da CEASA (desde já se desenha uma relação), é difícil precisar o alcance dessas ocupações. Elas não se apresentam como um contínuo espacial, tampouco o local é ocupado de modo homogêneo. As hortas desaparecem em alguns lugares para ressurgirem mais à frente, formam um arquipélago de pequenas ilhas produtivas, com cores e contornos bem particulares. Elas espraiam-se em uma área de convergência de bairros cujos limites são muito confusos. $\mathrm{Na}$ tentativa de definir um perímetro, cito os bairros do Curado e Jardim São Paulo (juntos são a área de maior relevância para esta pesquisa), Engenho do Meio, Torrões, San Martin e Barro.

Latitude, Vol. 2, nº 1, pp.26-42, 2008. 
No perímetro estão a Polícia Rodoviária Federal (PRF), o Departamento Nacional de Infra-estrutura de Transportes (DNIT), a Companhia Hidroelétrica do São Francisco (CHESF), o Tribunal de Justiça Federal (TJF), e instalações do exército brasileiro (o $4^{\circ}$ Batalhão de Polícia do Exército, a $10^{\mathrm{a}}$ Brigada de Infantaria Mecanizada e o Comando Militar do Nordeste). Um pouco mais afastada, situa-se também a Universidade Federal de Pernambuco (UFPE). A região apresenta importantes eixos viários tais como: Avenida Recife, Avenida José Rufino, Avenida São Miguel, além de um trecho do "Contorno do Recife", que constitui a referência espacial desta pesquisa.

Foi nos interstícios deste complexo viário, concluído no ano de 1980 ("Contorno do Recife"), que interliga a BR-101, BR-232, Avenida Recife e Avenida Abdias de Carvalho, que comecei a observar a emergência de "agricultores" e "hortas" inseridos em um processo de reapropriação/reinvenção do espaço pelo/para o uso do trabalho. Os agricultores e as hortas ocupam a faixa de domínio do "Contorno do Recife", uma reserva territorial nas margens da rodovia, de competência do DNIT (Departamento Nacional de Infra-estrutura de Transportes), que deve zelar pelo patrimônio da União, conforme explicita a Lei 10.233 de 5 de Junho de 2001. O tempo, os recursos e a energia disponíveis para esta pesquisa não me permitiram acompanhar o processo em toda a sua extensão, e a minha observação restringiu-se a 2 loops - expressão utilizada pelos engenheiros do DNIT - que compõem o referido complexo viário.

Estas presenças "irregulares", identificadas com o direito de escolha da população, confrontam a autocracia da racionalidade técnico-burocrática. Para o DNIT (que reivindica na justiça a reintegração da posse de sua faixa de domínio), a "abertura de hortas" neste espaço implica na:

"utilização não autorizada de bem público, ao mesmo tempo em que gera tensão e riscos, aos próprios esbulhadores e demais usuários. Não pode, portanto, ser tolerada no Estado Democrático de Direito" (...) "A atitude irresponsável dos réus está colocando em perigo suas vidas, bem como a dos usuários da rodovia, com o comprometimento da área destinada ao acostamento da via" (...) "É insuscetivel de qualquer espécie de regularização" (Processo $\mathrm{n}^{\circ}$ 2005.83.00.009874-5 - $6^{\text {a }}$ Vara de Justiça Federal).

Configura-se uma situação de tensão entre a engenharia profissional comprometida com os padrões do saber oficial, e a engenharia marginal resultante das tecnologias do saber difuso ("astúcias"), orientada para sua reprodução; entre uma racionalidade voltada para a previsão de riscos e para a manutenção do sistema de transportes, e uma racionalidade que "anda na cabeça, anda nas bocas", orientada por outros princípios e que encaminha soluções pessoais (e acaba sinalizando uma outra cidade possível). A flor amarela do quiabo (cultivo predominante nos loops da rodovia), "feia, mas realmente uma flor", simboliza essa ocupação. As hortas começam

Latitude, Vol. 2, nº 1 , pp.26-42, 2008. 
onde o asfalto termina, mas de um certo modo, elas furam "o asfalto, o tédio, o nojo e o ódio" (ANDRADE, 1986). Sua "forma insegura" se desenvolve a revelia dos atores sociais, habitualmente responsáveis pela produção do espaço. A "náusea" surge como uma reação da cidade a este "movimento".

Devo dizer, com certo grau de redundância, que as hortas vinculam-se à dinâmica sócio-espacial do Recife, àquilo que se considera a sua evolução urbana. Assim como a ocupação dos alagados pelos mocambos e mocambeiros, as hortas e os agricultores não são uma novidade na paisagem da cidade, mas representam um uso renovado de certos espaços, principalmente quando consideramos o seu caráter desviacionista, em relação a normatividade dos programas que regem os lugares. No século XVIII, o Recife será marcado pelo crescimento dos seus arredores. Sítios, pomares, hortas e roças surgem, pois, como desdobramento da falência dos engenhos (BARRETO, 1990), alguns deles situados na área observada nesta pesquisa.

Com o crescimento do centro urbano propriamente dito, estas práticas vão perdendo seu espaço na cidade, e passam a dar lugar aos bairros e ao seu uso habitacional. O bairro dos Torrões é um exemplo disso, seu nome deve-se ao fato de existirem na região algumas hortas, onde antigamente se cultivavam principalmente macaxeira e batata doce, que ao serem colhidas deixavam os "Torrões" de terra (CAVALCANTI, 2005). O avanço das casas sobre as hortas não se deu sem tensões. O exemplo de "Planeta dos Macacos" é característico. Esta ZEIS (Zona Especial de Interesse Social) situada no perímetro da pesquisa tem na sua origem, o conflito entre donos de roças de macaxeira do local e os novos ocupantes, que começaram a construir suas casas na área em 1975 (Divisão de Gestão de ZEIS, 2006).

De modo geral, a expansão das casas acabou reduzindo a oferta de terras agricultáveis, de maneira que as áreas ociosas abundantes nessa parte da cidade, muitas delas pertencentes ao DNIT, a CHESF, e mesmo a CEASA, parecem ter servido às populações circunvizinhas como uma possibilidade de trabalho e renda. A construção desta última certamente dinamizou a atividade agrícola no local, aproximando local de venda e local de produção (vale salientar a proximidade com os locais de moradia). Eu queria saber como tudo aquilo havia começado, como chegaram ali e "abriram" aquelas hortas, acessar a própria idéia-insight daquela ocupação. Para isto, apostei em uma análise que privilegiasse as trajetórias através do tempo-espaço. Orientei a minha observação para quatro momentos-movimentos do processo, situados em relação à "ocupação dos loops": o antes, a chegada, o durante e o depois.

Mais do que na "verdade" das coisas, devemos nos concentrar no "movimento" das coisas. A "história de vida" foi utilizada como método de pesquisa capaz de apreender a dimensão processual da minha problemática (QUEIROZ, 1988; HAGUETTE, 1997; DAVIS, 2003). As "histórias de vida" fornecem ao pesquisador os aspectos mundanos da vida humana, que os paradigmas que enfatizam a macroestrutura deixam de fora. Permitem "comprender las experiencias de las personas y

Latitude, Vol. 2, nº 1 , pp.26-42, 2008. 
mostrar como manejan éstas sus vidas bajo condiciones de pobreza, opresión, exclusión o cambios sociales" (DAVIS, 2003, p. 154). A primeira pesquisa a utilizar este método, ou seja, a considerar as "histórias de vida" como material sócio-antropológico, foi realizada por Thomas e Znaniecki (1918-1920) - El campesinato polaco en Europa y América. Eles estavam interessados nas mudanças ocasionadas na sociedade de chegada e de origem destes migrantes, decorrentes da migração. Segundo Davis, a Escola de Chicago levou este método mais longe, utilizando a história de vida para "ampliar sus estudios de campo sobre los grupos sociales de indigentes, marginados o outsiders" (DAVIS, 2003, p. 153).

A pesquisa envolveu apenas os "donos de hortas" dos loops. Do universo de 10 agricultores que atuam na área, 7 participaram da pesquisa: Marcos (46 anos), Tiago (38 anos), Paulo (40 anos), Pedro (39 anos), João (37 anos), Lucas (42 anos) e Mateus (29 anos) - nomes fictícios para experiências reais. Através de conversas informais, tão caras ao trabalho do antropólogo, fui acessando momentos das trajetórias de cada um dos 7 agricultores, individualmente. Cada momento foi trabalhado separadamente com eles, mas aos poucos eu reconstruía os seus percursos no meu diário de campo. Só quando estas conversas atingiram a maturidade, eu realizei uma entrevista longa, de modo a recolocar cada "momento" no corpo do "movimento". Nestas entrevistas, também individuais, eu provoquei os agricultores a remontarem suas trajetórias integralmente, de modo a sistematizar aquelas histórias que eu ouvi de modo fragmentado.

O passado do lugar me chegou através da memória dos agricultores que o ocupavam:

\begin{abstract}
"aqui antigamente, isso aqui era jardim. Não tinha negócio de horta não. Só era jardim. Do lado da estauta ali, isso aqui era tudo grama, jardim, a turma trabalhando, só jardineiro. Era somente jardineiro mesmo" (Pedro - agricultor 4).
\end{abstract}

As únicas evidências materiais que acusam a existência passada de uma praça (Conde Pereira Carneiro) em um dos loops, é o trecho de calçamento remanescente, alguns postes (sem luminárias) e mastros, e de modo mais expressivo, o espelho d'água (que já não reflete nada) e uma escultura (referência à união de brancos, negros e índios, contra os holandeses, na Batalha dos Guararapes) feita por Francisco Brennand. O lugar foi abandonado pelo poder público, e há muito tempo (no mínimo 12 anos, considerando o último registro da EMLURB - Empresa de Manutenção e Limpeza Urbana) está desassistido, como diz João e confirma Pedro.

Latitude, Vol. 2, nº 1 , pp.26-42, 2008. 


\begin{abstract}
"Quando eu peguei isso aqui, isso era tão duro, era aterro da BR. Quando foi feita a BR aterrou isso aqui tudinho, pra fazer isso. Era um jardim, isso aqui. Ai o governo deixou acabar, dentro do mato, como eu disse ao senhor, desova de gente dentro do mato, era um matagal" (João - agricultor 5).

"Antigamente, quando não eu não trabalhava com esses negócio, isso aqui era tudo cheio de mato aqui. Agora, eu sei que antigamente antes de eu chegar aqui pra trabalhar, que eu viajava muito, pra Natal, Petrolina, Maceió. Viajava pela firma empeleiteira, né? Isso aqui era cheio de mato. Agora isso aqui era o que? Era assalto, que nem assaltava o ônibus de Jardim São Paulo. Assaltava ali, isso aqui era tudo cheio de mato. Tinha vez o carro do IML pegava um que os caba assaltava e trazia pra cá pra dentro e matava" (Pedro - agricultor 4).
\end{abstract}

O mato alto é o cenário inicial para todos que chegaram para "abrir suas hortas". O terreno configura-se como um "baldio", ao mesmo tempo um adjetivo "sem proveito" - e um substantivo masculino - "terreno por cultivar" (FERREIRA, 1988, p. 82). O que eles fazem é aproveitar cultivando. Todos eles sabem que estão em terras da União, ocupando as margens de uma rodovia, que não foram programadas para o trabalho agrícola. "Isso aqui não foi feito pra nós, foi feito pra BR", ao dizê-lo, Paulo pensava em duas coisas: os alagamentos e as condições da terra. Mas estes agricultores-alquimistas, com suas enxadas-filosofais ${ }^{1}$, vão transformando o lugar. "Isso aqui não tinha terra, né? Era só o barro vermelho. O barro vermelho, com a continuação, você vai virando, virando, virando, vai ficando preto, né? Vai botando esterco, adubo, mata alguns insetos por a $\imath^{\prime \prime}$ (Lucas - agricultor 6).

O processo de reapropriação/reinvenção implica em um trabalho - uma série de atos de ocupação. O trabalho inicia um circuito de transformação. Ao mesmo tempo em que os loops são reutilizados pelo/para o uso do trabalho, eles são ressignificados como espaços de trabalho. Nesse caso, "chegar" significa: 'roçar', 'limpar', 'preparar a terra', 'fazer o canteiro', 'irrigar', 'colher'. "Aí se a pessoa chegar, aí vai ter que colocar energia, vai ter que cavar poço", assim me explicou Marcos. Trata-se de um uso "astucioso" do espaço, e no campo das astúcias tudo é oportunidade.

É assim que os interstícios do "Contorno do Recife" se apresentam a Marcos, Tiago, Paulo, Mateus, João, Lucas, Pedro - e a todos os outros que com, e como eles, ocupam essa área com suas hortas e/ou casas - como uma oportunidade não só de trabalho (embora este uso seja a "marca" da ocupação no local observado), ou de moradia (outro uso dado ao local); mas de viabilização da vida, em um ambiente altamente concentrador de riquezas e oportunidades, onde o trabalho ocupa uma

1 Referência à "pedra filosofal" do alquimista que tem o poder de transformar uma matéria inferior em um objeto nobre.

Latitude, Vol. 2, n¹, pp.26-42, 2008. 
posição de centralidade, e ao mesmo tempo em que é fonte de exclusão, torna-se um fator de inclusão. A desocupação da área e a reintegração de sua posse ao DNIT institui o fim de uma "oportunidade", cancela a relação, ou antes, a "aliança" entre o homem e a terra, que constituiu "agricultores" e "hortas"; e reposiciona-os como "desempregados" e "baldios", respectivamente.

Pela cidade, vemos florescer ocupações/usos irregulares, como que regados pela "impotência" do Estado, pela espoliação do Capital, pelo consentimento sutil da sociedade - ainda que estas mesmas instituições os rechacem - e pela "sabedoria daqueles que vivem no cotidiano situações altamente excludentes" (KOWARICK, 1979, p. 117). (CERTEAU, 1994) nos fala de "astúcias". Essas "astúcias", "maneiras de fazer", "modos de operação", "esquemas de ação", "caça não autorizada", "arte de dar golpes", "inventividade artesanal", "criatividade dispersa, tática e bricoladora", entoam uma só nota: os indivíduos não se entregam passivamente à disciplina, e escapam ao poder, sem, no entanto, deixá-lo. A cidade é reinventada cotidianamente por heróis anônimos que se reapropriam do espaço e o recompõem.

"Contando com suas astúcias" (e baseando-se em uma "filosofia da enxada"), estes sujeitos (portadores de um heroísmo coletivo) aproveitaram uma "oportunidade" de viver (tentativa/erro), e com o que tinha a mão, fizeram dela uma possibilidade de vida (funciona/ não funciona). Com suas "enxadas filosofais" (roçando, limpando, preparando a terra, fazendo canteiro, irrigando, colhendo), eles reapropriaram-se do espaço (hortas) e reinventaram-se com ele (agricultores), restabelecendo a comunicação com a terra. O princípio fundamental deste processo são as sucessivas "reavaliações funcionais" em curso. A partir do questionamento prático dos usos previstos para os espaços, estes "heróis ordinários" sujeitam as funcionalidades estabelecidas a um "risco empírico" (Sahlins, 1999), e põem em xeque os "lugares" definidos pela racionalidade técnico-burocrática, desviando da programação oficial.

"É o seguinte, você não tem prá onde fazer nada mesmo. Passei, via a área desocupada, o cara vem e começou a trabalhar" (Lucas - agricultor 6). Este é o "instante da arte" - uma decisão mais do que um discurso. Na periferia do mundo, o peso destas iniciativas informais é bastante relevante. Pedro nos oferece um exemplo da extrema desenvoltura que esses heróis têm, abrindo "brechas" e inventando alianças, que possibilitam viver em um ambiente altamente concentrador e excludente. Ele não tinha nenhuma relação anterior com a agricultura: "Aí prá puder plantar, vim pra cá, comecei a aprender com os meninos, com os colega, né? Comecei a amizade com os menino". Mas Pedro é uma exceção. Para os outros, "já vem hereditário (...). Meu pai já veio, não era do ramo, mas casou com a minha mãe que já mexia no ramo, aí ele entrou pro ramo e não saiu mais não. Um vai trazendo o outro" (Paulo - agricultor 3 ). Todos se iniciaram na agricultura por volta dos 10 anos de idade, trabalhando com os pais.

Latitude, Vol. 2, nº 1 , pp.26-42, 2008. 


\begin{abstract}
"Eu comecei a trabalhar com oito anos de idade, com enxada lá, plantando verdura mais meu pai. Oito anos de idade, eu nasci e me criei dentro da horta. Eu não entendo muito não, mas entendo um bocado, entendeu? Sei plantar, sei colher, desde menor que ele (aponta para o filho de 12 anos), eu trabalhava na enxada já, menor do que ele. Com coentro, alface, cebolinha também" (Tiago agricultor 2).
\end{abstract}

João trabalha na agricultura desde os 12 anos. "Lá era do meu pai (...). A gente trabalhava, criava uns gado e trabalhava fora (...) Mas não tinha condição de trabalhar lá não, que é muito barato demais a mercadoria". Marcos começou a trabalhar com 10 anos no sítio da família. "Lá no sítio, meu pai só planta quiabo, não planta alface não". Os avós e bisavós de Paulo já cultivavam outras áreas no Recife: próximo ao Hospital Getúlio Vargas (bairro do Cordeiro) e depois na Cidade Universitária (onde hoje se situa a Universidade Federal de Pernambuco - no Campus ainda existe um pequeno sítio). Aos poucos, foram sendo empurrados para fora da cidade esterilizada pelo asfalto, encaixando-se nas suas "brechas", resistindo aos "apagamentos".

"Depois chegou a universidade, né? Evoluiu mais. Aí voltaram pro interior ai depois voltamos de novo. Eles começaram aqui já vai na terceira geração já. Já vem genético (...) Eles plantavam mas lá era muito devagar, foi os primeiro que começou, na época não existia nem esses motor a explosão, tocava naquela bomba manual, muito arcaico ainda, depois foi evoluindo. Eles também, a cidade cresceu, né? Eles foram-se embora pra zona rural de novo, mas sempre eles estão por aqui. Tão aqui acho que mais de 30 anos. Mais do que isso" (Paulo - agricultor 3).

Eis que a migração se apresentou como uma importante energia no processo reapropriação/reinvenção daquele espaço. O contexto da ocupação é marcado pelo recebimento de migrantes, ao menos nos dois loops que serviram de referência espacial para a minha observação, mas não há porque achar que isso é inválido para outras áreas próximas, principalmente a área de expansão da CEASA, e a que se prolonga pela BR-232. O movimento Vitória de Santo Antão - Recife mostrou-se o principal na área. Deixando de lado o binômio repulsão/atração, acredito que dois fatores tenham contribuído conjuntamente para esta migração, considerando também o movimento realizado a partir de outras cidades-origem, a exemplo de Catende. Foram eles, a construção da CEASA na década de 1960 e a própria constituição/consolidação de uma Região Metropolitana da qual o Recife se fez centro, na década de (19)70 (ANDRADE, 1979). Embora a área de expansão da CEASA não tenha integrado o campo observado nesta pesquisa, pode-se dizer que ela tem certa centralidade no processo de reinvenção/reapropriação do espaço, recebendo estes migrantes ao longo

Latitude, Vol. 2, nº 1 , pp.26-42, 2008. 
dos anos; mesmo que este não tenha sido o primeiro destino para alguns deles, ou o próprio propósito de suas vindas para o Recife, mostrou-se como uma possibilidade de vida na cidade, a qual eles foram aderindo.

Embora, como diz DURHAM (1973), os imigrantes do campo não tragam em si diferenças culturais suficientes, tal qual ocorre com os imigrantes estrangeiros, para criarem a consciência de uma situação comum, "como a que preside a formação de comunidades étnicas"; o contexto migratório produziu um ambiente de relações de parentesco, compadrio, conterraneidade, vizinhança e amizade, que se superpõem na área de expansão da CEASA. Este é um dado bastante característico do universo de relações pessoais dentro do qual se orienta a migração, conforme diz DURHAM: "Esse grupo constitui um instrumento importante para a integração do migrante no universo urbano e, especialmente, no ocupacional" (1973, p. 183). No entanto, esta "mobilização de parentes, vizinhos e conterrâneos não constitui um resíduo de padrões tradicionais, que tenderiam a sumir com o progresso da urbanização, mas são relações atualizadas na vida urbana $e$ constitutivos dela" (SADER, 1988, p. 95).

Pode-se dizer que essas relações foram decisivas na vinda de Marcos, Paulo, Tiago, Lucas e João (citando apenas aqueles que participaram da pesquisa e vinculamse ao contexto migratório) para o Recife (facilitando essa "chegada" como um "caminho" já aberto), e desempenha um importante papel no processo de reapropriação/reinvenção que se desenrola nos espaços adjacentes a CEASA. Para se "objetivarem", "hortas" e "agricultores" precisam ser "reconhecidos" como tais. Tal "reconhecimento" (inclusive do "direito de posse") é, sobretudo, "local". Ele deriva, em grande parte, das alianças que os indivíduos conseguem mobilizar intra e extra loops, e é ele que garante um mínimo de estabilidade ao vínculo agricultor-horta.

Praticamente toda a família de Paulo já está no Recife, só não os mais velhos, mais apegados a terra.

\begin{abstract}
"Por causo que um vai trazendo o outro, vai vendo. Outro: comoé que tá tua situação lá? Tá devagar demais. Então vem pra cá. Não é bom não mas parece que tá melhor do que lá. Aí foi chegando, foi chegando, foi chegando, acho que a familia inteira tá aí. Todos que vieram pra aqui não voltaram pra lá não. E as terra continua lá mesmo, os parentes continua lá, eles também não sai de lá, porque é a $3^{a}$ geração já, eles também não sai de lá. E agora que iluminação rural melhorou um bocado lá também. Mas os que vieram pra aqui não voltaram pra lá não" (Paulo - agricultor 3 ).
\end{abstract}

Nada pude observar que denotasse que o parentesco (sobressaindo-se as demais relações) constitua uma regra de acesso a terra, mas eles são todos (com exceção de Pedro e Mateus) atravessados por relações de parentesco, que se estendem além dos dois loops. Para Tiago, "aqui é quase tudo familia". Lucas "mora" com a irmã de João e é

Latitude, Vol. 2, n¹, pp.26-42, 2008. 
primo da esposa de Marcos. Este é casado com a irmã de Paulo e é primo segundo de Tiago. Há outros parentes de Marcos, Tiago, Paulo e Lucas, cultivando outras hortas, em outras áreas ociosas daquela região. Salvo João, nascido em Catende (Zona da Mata de Pernambuco - distante $142 \mathrm{Km}$ do Recife), suas histórias entrecruzam-se no Engenho Galiléia, "onde começou as liga camponesa em 64" (Marcos - agricultor 1), em Vitória de Santo Antão, famoso pomar pernambucano, de terras férteis e bem regadas, na Zona da Mata - distante $51 \mathrm{Km}$ do Recife.

A Sociedade Agrícola e Pecuária dos Plantadores de Pernambuco ficou mais conhecida pelo seu apelido, Ligas Camponesas, que visava dar-lhe uma origem suspeita associando-a a um "perigo comunista". No entanto, a Liga não estava "ligada" às lutas contra a exploração do regime agrário, seu objetivo inicial era a defesa dos direitos dos mortos a "sete palmos de terra e um caixão", já que os caixões eram emprestados pela Prefeitura e precisavam ser devolvidos para servir a outros. A Liga era uma "sociedade civil beneficente de auxílio mútuo", ela pagava o enterro e o caixão descia com o morto, um pequeno perigo que foi alimentado por um grande medo, conforme diz Castro (1965). Entre os agricultores dos loops há descendentes de "Zezé da Galiléia", importante liderança camponesa, evocado com orgulho. Para Augé, "a própria referência ao passado é um ato de criação e, pode-se dizer, de mobilização" (1998, p .28).

Marcos e Tiago nasceram e criaram-se no referido engenho, onde seus pais ainda residem. "Desde a desapropriação que meu pai mora lá, nasceu lá e criou-se lá. Hoje ele tá com 70 anos" (Marcos - agricultor 1). Eles vão à Vitória com uma certa freqüência, aproveitando alguns finais de semana, para ver a família, "tomar banho de cachoeira".

"A terra de Vitória é do meu pai, é própria, é do meu pai lá. O terreno lá era grande demais, e é grande ainda, ainda mora gente lá. Tem casa lá também, tem lá. Final de semana eu sempre vou prá lá, final de semana pra lá eu vou. Passar final de semana com meu pai e minha mãe lá" (Tiago - agricultor 2).

Marcos saiu de Vitória de Santo Antão em 1988 para trabalhar como ajudante geral na fábrica de cerâmica da família Brennand. "Eu arranjei esse emprego através de um parente, que ele trabalhava na Brennand. Ele é casado com a prima da minha esposa. Aí ele arranjou pra mim esse serviço e eu trabalhei 3 anos e 8 meses". Até a falência desta fábrica, em 1992. "Ai resolvi trabalhar na enxada de novo". Na verdade, ele voltou a ter a agricultura como atividade principal, pois que nunca deixou a enxada, "plantava pouquinho, mas plantava". Ele é um dos mais antigos na área, está lá há 18 anos, embora só há 7 nos loops. Ele participou da primeira associação de agricultores daquela área.

Enquanto Marcos estava empregado na Brennand (Fábrica de Cerâmica São João), a agricultura era a sua segunda atividade, trabalhando com Lucas e o pai na área

Latitude, Vol. 2, n¹, pp.26-42, 2008. 
que eles cultivavam próximo ao atual Núcleo de Educação Física no Campus da UFPE - onde morou por 1 ano quando chegou no Recife, depois a Universidade precisou do terreno e "indenizou a gente com uma micharia lá" (Lucas - agricultor 6) - ou cultivando a sua própria horta na área de expansão da CEASA (onde mora atualmente). Ao sair da fábrica voltou a dedicar-se exclusivamente a agricultura. O mesmo ocorreu com Lucas, que trabalhava na Prefeitura do Campus, "naquelas firma de limpeza de lá", enquanto cultivava sua horta. Ao ser demitido passou a ter a agricultura como única atividade essa é a realidade para os 7 casos observados: a agricultura é praticada com exclusividade.

Lucas nasceu em Vitória de Santo Antão, mas foi criado no Recife. Caminho inverso fez Paulo que nascido aqui, criou-se em Vitória.

"Lá o clima é outro, é muito mais gostoso do que aqui. Principalmente pra dormir, não tem melhor não. É um clima de montanha, você pode dormir sossegado, sem ninguém tá enchendo o saco. Na cidade você sabe como é que é, moro na Roda de Fogo, pertinho da avenida. Paciência. Minha casa é fechada que não dá pra ver o sol, tô dentro de uma estufa" (Lucas - agricultor 6).

Paulo "trabalhava de metalurgia, setor de borracha e comércio, três serviço, eu tenho três carteira pra trabalhar em qualquer serviço. Se não dá num outro vai". Passou 5 anos em São Paulo, e chegou definitivamente para viver no Recife em 1992, por conta de um problema de saúde a família não lhe deixou voltar.

"São Paulo eu fui em 87 , passei 5 anos lá. Aí inventei de vir pra
aqui, aí tinha um problema de visão. Aí piorou o meu problema de
saúde, eu não tive mais como voltar. Aí tive que fazer uma cirurgia.
Aí ficou até aqui, não dava pra voltar mais, eu permaneci aqui
mesmo. Num vai, num vai, a familia tudo dizendo, passou 5 anos lá
não deu muito certo, também não vai enricar, pobre não enrica
assim fácil. Fiquei por aqui mesmo, o problema de saúde agravou-se
não teve como voltar mais não. Passei uns 3 anos pra me recuperar
da cirurgia, ou mais, tô me recuperando muito lento (...) A gente já
praticava mais de uma atividade já, quando não dá a gente vai pra
indústria (...) Tem uma linha assim na indústria né? Todos tão
mais ou menos com 39, 40 anos e ficaram mais ou menos 15, 20
anos na indústria, aí as indústria foi fechando e a idade foi
colaborando, aí cada vez que ficava mais difícil. Vamo pra feira, aí
vamo evoluindo!" (Paulo - agricultor 3).

Tiago chegou de Vitória com toda a família (esposa e 2 filhos) em 1999, "lá em 99, lá foi muita seca lá, e o açude de lá secou. Aí não deu pra trabalhar, aí vim prá cá. Aí comprei

Latitude, Vol. 2, nº1, pp.26-42, 2008. 
uma hortinha aqui e fiquei aqui, em 99, já faz o quê? Já faz sete anos, né? Sete anos que eu tô aqui já. Sete anos". Eles foram morar na área de expansão da CEASA, onde Tiago adquiriu a primeira horta. "Tem muita gente lá, casa boa, de tijolo" (Tiago - agricultor 2). Sob o pretexto de precisar da área para a ampliação das instalações, a CEASA vem indenizando algumas famílias para que elas deixem o local, e já começou a construção de um muro para evitar que novas famílias cheguem na área para construir novas casas e "abrir" novas hortas. No início do ano de 2006, Tiago adquiriu uma horta em um dos loops, "o rapaz aqui resolveu vender aqui, aí eu comprei a Antônio", mas ele ainda conserva sua horta na área de expansão da CEASA. Ele veio com a intenção de trabalhar na mesma atividade que praticava em Vitória, e já tinha um lugar certo para ficar. Embora ele soubesse do desenvolvimento da agricultura naquela área, desconhecia as origens daquela ocupação.

"Quando eu cheguei por aqui já tava tudo assim já. Tudo cheio de lavoura já. Quem deve saber é quem abriu aqui, quem abriu a horta aqui, que é mais velho aqui. Quem abriu a horta aqui não tá aqui mais não. Vendeu para outro e foi embora. E é assim, né? Quando dá pra uma pessoa, dá. Quando não dá, não dá, ele vende e vai se embora, né? Tanto faz. E que nem uma pessoa tá morando em uma casa alugada, quando a casa própria não é dele mesmo, não dá pra morar naquela mais, vende aquela casa e bota em outro lugar, né?" (Tiago - agricultor 2).

Do conjunto dos agricultores apenas Tiago e João nunca "empregaram-se". Este já está no Recife há mais ou menos 25 anos, chegou com 12 anos e inicialmente negociava na feira. Ele trabalhava no corte de cana-de-açúcar em Catende. Foi sua irmã que o trouxe para o Recife, ela já estava na capital trabalhando como doméstica no Engenho do Meio, "aí ela perguntou se eu queria vir pra cá, é eu vou ver se dá pra vim", e ela foi buscá-lo. A liberdade de horário é apontada como uma vantagem do trabalho na horta que se contrapõe às vantagens do trabalho "empregado". Neste sentido, o "emprego" - como trabalho subordinado - é desvalorizado pela negação da liberdade de dispor de si mesmo enquanto força de trabalho, em consonância com o que a literatura científica diz sobre as relações trabalhistas na indústria. Marcos, que já "empregou-se", pondera:

"É quase igual, né? Lá, porque nós temos direito de emprego, tem salário, tem FGTS, tudo pago, e se por acaso sair, tem o seguro desemprego, e aqui nós não temos nada, né? Só, nós somos autônomos, não tem aquele problema de tá fixado lá, de ter aquelas hora de entrar e sair. Aqui a gente não tem esse horário. Tanto faz tá agora aqui trabalhando, aí precisa sair, sai não tem problema nenhum, chega a hora que quiser. O bom de quem trabalha pra sié isso" (Marcos, agricultor 1).

Latitude, Vol. 2, n¹, pp.26-42, 2008. 
Lucas é o único entre os que já trabalharam "empregados" a preferir o emprego,

"você tinha seu INPS, tinha alguma coisa, né? Férias, décimo sabe o que é num sabe? - aqui você não tem décimo, não tem férias, não tem chuva, não tem sol, aqui ói, é pra cair o cabelo mesmo. Só trabalha, trabalha, trabalha... quando dá, né? Quando dá. Você passa uma fase boazinha, pronto, agora vai melhorar, vai começar, o quiabo tá começando a chegar, já melhorando vai desafogar um pouquinho, depois que acabar o quiabo todinho pronto, você começa tudo de novo. Vira, planta tudo de novo, outra temporada meia ruim. E por aí vai" (Lucas, agricultor 6).

\section{Considerações finais}

Esta é parte da experiência que acompanhei durante a pesquisa que realizei entre agricultores nas margens de uma rodovia federal no Recife-PE. A partir dela, fica bastante evidente a participação da migração no processo de reapropriação/reinvenção do espaço, bem como a relação íntima que existe entre imigrante e trabalho, conforme acusa Sayad (1998). Para o autor, o trabalho consiste na própria razão de ser do imigrante, e "toda imigração de trabalho contém em germe a imigração de povoamento que a prolongará" (SAYAD, 1998, p. 67). Pode-se dizer, no entanto, sem prejuízo para as considerações anteriores, que o trabalho traduz, mas só parcialmente, uma parte da busca do imigrante por um "lugar".

Uma relação ainda mais íntima que a apresentada, ou que se associa a ela formando um triângulo amoroso, é a que existe entre imigrante e cidade - e que nos faz pensar a questão da(s) alteridade(s). A cidade atende "a desejos e necessidades tanto conscientes quanto inconscientes" (SANTOS, 1998, p. 77), sobretudo, um desejo de segurança e de emancipação frente à natureza, contra a qual ela se "revolta" (LE CORBUSIER, 1992). Como local onde (e de onde) o poder se exerce, a cidade reivindicou a sua centralidade, e (a)traiu imigrantes de toda a parte, adensando-se, acelerando-se, intensificando-se, expandindo-se. Nada encantou tanto o imigrante como a cidade, e ele a transformou na "grande morada da humanidade" (MUMFORD, 1998). Como conceber a cidade sem a "força" desses imigrantes que depositaram nela toda a sua "fé"? Como conceber a cidade sem esse "excesso" que representa a imigração? "Um excesso real de gente no espaço real, porque só esse excesso permite a passagem da idéia de aldeia para a idéia doutra coisa não apenas maior, mas diferente: a cidade" (PIMENTA, 1989, p.406). A cidade se vale deste "excesso" e com ele estabelece uma relação complexa. Se para a cidade orgulhosamente capitalista, este "excesso" constitui-se em uma das principais alavancas de acumulação, que contribui de todas as maneiras para a consolidação do seu luxo (sem dele participar); ele também é

Latitude, Vol. 2, nº 1 , pp.26-42, 2008. 
responsabilizado pelos graves problemas que rondam a cidade "inchada". O crescimento populacional é tomado como a comprovação do seu sucesso, mas só enquanto "a 'ordem pública' estiver a salvo (a ordem politica, social, moral, mas também a ordem externa, a ordem estética, aquela que o panorama de uma presença demasiadamente grande de imigrantes disparatados viria turvar)" (SAYAD, 1998, p. 57).

No Recife, aos que vieram de longe, de terras distantes, com poucas ou nenhuma posse, retirantes em busca de um pedaço de chão, restou os "alagados" - que depois thes seriam retirados e utilizados como meios de exploração. Os alagados se mostravam como a única saída. "Só o mangue e o mocambo estavam à altura de suas posses [...] no mangue não se paga casa, come-se caranguejo e anda-se quase nú" (CASTRO, 1967, pp. 27-28). Foi ele, o mocambeiro, o principal construtor do espaço recifense. Os mocambeiros fixavam-se naquelas terras. Enraizados como os mangues na lama dos alagados, trazidos pelos rios como aluviões repatriados. Eles não construíram apenas as suas casas, eles inventaram o próprio chão que ocupavam, através de uma engenharia bastante simples: "enfiar o pau na lama".

Por este trabalho, que predominou sobre todos os outros - ibérico e flamengo o mocambeiro é o personagem principal do processo de criação e consolidação do espaço do Recife. Não há categoria mais adequada que esta, que melhor exprima o status dos inventores do espaço recifense e a qualidade do trabalho empreendido na sua construção (MELO, 2004). O construir é um ato sagrado, "é um ato religioso, o estabelecimento de um mundo em meio de uma desordem primeva" (TUAN, 1983, pp. 116117). Ao "enfiar o pau na lama", os mocambeiros participam de um modelo arquetípico ligado à fundação da cidade. Segundo Eliade (1992), desta maneira eles se tornam paradigmáticos.

Foi o mocambeiro quem beneficiou a área com suas casas de palha, tábua ou pau a pique. Não criaram menos que um mundo, mas a eles só coube criar. O solo do Recife é obra de mangues aterrados e de homens desterrados. O mangue e o mocambeiro sempre estiveram sob a constante ameaça de perder o seu lugar, fosse pelo avanço das águas ou dos homens. Depois que o trabalho de criação e consolidação do espaço do Recife estava concluído, mangue e mocambeiro foram considerados inimigos da paisagem (MELO, 2004). Essa situação, em seus inícios nordestinos, está amplamente representada na literatura de Josué de Castro (1967), de João Cabral de Melo Neto (2000), de Graciliano Ramos (1999), etc. Expulso do campo depois de plantar, expulso da cidade depois de construí-la, "Severino" - principal imagem do imigrante nordestino - vê-se um errante.

Essas classes experimentam a morte, não apenas em sua versão biológica, mas a morte social, cultural, moral, que só os homens são capazes de impor, através de espoliações que se superpõem em um processo extenuante. Não são identificados como consumidores, para os quais a cidade se abre; mas como "classes perigosas", para as quais a cidade se fecha. Trata-se de uma teoria da suspeição generalizada, que

Latitude, Vol. 2, nº1, pp.26-42, 2008. 
é o paradigma da nossa relação com a alteridade. Ela se vale da "terrível sensação de estranhamento que um homem sente pelo outro" (CARVALHO, 1997, p. 32). A cidade, que se ergueu sob o mito da segurança (LE GOFF, 1998), vive o fantasma da insegurança um movimento impossível de gerir. Quanto mais se enfatiza a ordem, mais o caos torna-se aterrorizante. $\mathrm{O}$ medo é, por excelência, o sentimento da cidade.

Com o intuito de afastar tudo aquilo que ameace a estabilidade do seu edifício, a cidade tenta escamotear suas contradições e manipular as evidências que testemunham contra o seu falso semblante de ordem única, de equilíbrio perfeito, de sucesso técnico e de progresso certo. Ela encobre a sua própria resistência "em absorver os trabalhadores e a determinação destes em se instalar" (BLAY, 1979, p. 154), responsabilizando-os ("os outros") pelo seu "inchamento", pela sua desordem. Cabe aqui, rejeitar a imagem do "estranho no ninho", que impõe ao imigrante (do campo) toda a responsabilidade pelo seu "(não)ajustamento" aos padrões urbanos, e principalmente, ao mundo do trabalho.

O narcisismo e a arrogância fizeram de nossas cidades um "espaço de crueldades" contra os seres do mundo. Desenvolvemos múltiplas formas de torturar e excluir, de humilhar e ofender a vida (MELO, 2007). Mecanismos perversos que tentam manter a pobreza longe das áreas mais bem urbanizadas das cidades, como diz Rolnik (2004), e que se ocultam sob o "humanitarismo" dos argumentos dos nossos "guardiões públicos" (QUINN, 2001). Para "libertar Pernambuco do ultrage dos mocambos" ${ }^{\prime 2}$ o argumento utilizado sempre foi o sanitário, mas a higienização possuía um outro sentido: sócio-econômico-cultural. Conforme diz Douglas (1976, p. 16), "a reflexão sobre a sujeira envolve a reflexão sobre a relação entre a ordem e a desordem" (não se trata, pois, de reduzir a sujeira a sua dimensão higiênico-sanitária). Essencialmente tratava-se de um combate ao pobre, que se constituía em perigo, não só por ameaçar a ordem pública, mas por ser contagioso.

De fato, o outsider é quase sempre associado ao "inumano", ao "sujo", nos diz Elias (2001). O lixo, o "socialmente poluente", compartilha o espaço dos amantes, e de todos aqueles cuja vergonha e/ ou a indiferença, impõe uma vida de sombra e segredo. Compõe um inconsciente visual, torna-se uma imagem impedida, uma presença não reconhecida, uma ausência. Nega-se-lhe a existência. Como não pode ser destruída, a sujeira - aquilo que ofende e ameaça a ordem - é destinado a um lugar fora do lugar, um "não-onde". O "não-onde" tem um contorno próprio e em nada diz respeito ao "não-lugar" de Augé (1994), que se apresenta em estado de fluxo, insensível a tudo o que passa por ele, locus de uma experiência "irrelacional" incapaz de fecundar identidades e produzir vínculos. O "não-lugar" não se realiza completamente, da

2 Extraído do discurso do jornalista José Campello, proferido na entrega do projeto de remodelação do bairro de Santo Antônio - Recife, em 1938, denotativo do espírito da higienização (OUTTES, 1997, p. 53).

Latitude, Vol. 2, nº1, pp.26-42, 2008. 
mesma forma que o "lugar" não é totalmente apagado, para o autor, um e outro são "polaridades fugidias".

O "não-onde", ao contrário, realiza-se como um "lugar" de rejeição social, sem que isso comprometa suas propriedades "topofílicas", aquele elo afetivo que os indivíduos e grupos estabelecem com o lugar, segundo Tuan (1980). Ele remete não ao "fluxo", mas a "sociodinâmica da estigmatização", as tensões e conflitos entre estabelecidos e outsiders (ELIAS, 2000) - que sinalizou sua centralidade nesta pesquisa. A articulação proposta neste artigo - cidade, migração e alteridade - mostra-se bastante fecunda. No momento em que a (in) segurança pública torna-se o tema de maior destaque nos meios de comunicação, e o medo do "outro" e a intolerância aumentam, vê-se que aquilo que tratamos, por muito tempo, como segregação sócioespacial, é um modelo de "gestão da alteridade", empregado por uma ordem cada vez mais excludente e fóbica, que espanca o outro e tenta impedi-lo de praticar a cidade. No entanto, "a rua sente nos nervos essa miséria da criação e por isso é a mais igualitária, a mais socialista, a mais niveladora das obras humanas" (RIO, 1910, p. 5), e desse modo, parece escapar de todos aqueles determinismos pretendidos pelos agentes habitualmente responsáveis pela sua regulação.

\section{Bibliografia}

ANDRADE, Manoel Correia de. Recife: problemática de uma metrópole de região subdesenvolvida. Recife: Universitária, 1979.

ANDRADE, Carlos Drummond de. Antologia Poética. 20 a ed. Rio de Janeiro: Record, 1986.

AUGÉ, M. Não-lugares: introdução a uma antropologia da supermodernidade. São Paulo: Papirus, 1994.

A Guerra dos Sonhos: exercício de etnoficção. São Paulo: Papirus, 1998.

BARRETO, Ângela Maria Maranhão. O Recife através dos tempos - formação de sua paisagem. Recife. Geografia [Dissertação (mestrado)]. Universidade Federal de Pernambuco, 1990.

BLAY, Eva Alterman. A luta pelo espaço: textos de sociologia urbana. Petrópolis: Vozes, 1978.

CARVALHO, Edgar de Assis. Polifônicas idéias: antropologia e universalidade. São Paulo: Imaginário, 1997.

CASTRO, Josué de. Sete palmos de terra e um caixão: ensaio sobre o Nordeste - área explosiva. São Paulo: Brasiliense, 1965.

Homens e caranguejos. São Paulo: Brasiliense, 1967.

Latitude, Vol. 2, nº 1, pp.26-42, 2008. 
CAVALCANTI, Carlos Bezerra. O Recife e seus bairros. $2^{\mathrm{a}}$ ed. Recife: Câmara Municipal do Recife, 2005.

DAVIS, Kathy. La biografía como metodología crítica. Memoria Rerum, n 30, p.153-160, 2003.

CERTEAU, Michel de. A Invenção do cotidiano: artes de fazer. $7^{\mathrm{a}}$ ed. Petrópolis: Vozes, 1994.

DIVISÃO DE GESTÃO DE ZEIS. Planeta dos macacos. Recife: Divisão de Gestão de ZEIS, 2006.

DOUGLAS, Mary. Pureza e perigo. São Paulo: Perspectivas, 1976.

DURHAM, Eunice Ribeiro. A Caminho da cidade: a vida rural e a migração para São Paulo. São Paulo: Perspectiva, 1973.

ELIADE, Mircea. Mito do eterno retorno. São Paulo: Mercuryo, 1992.

ELIAS, Norbert. Os Estabelecidos e os outsiders: sociologia das relações de poder de uma pequena comunidade. Rio de Janeiro: Jorge Zahar, 2000.

FERREIRA, Aurélio Buarque de Holanda. Dicionário Aurélio Básico da Língua Portuguesa. Rio de Janeiro: Nova Fronteira, 1988.

HAGUETTE, Tereza Maria Frota. Metodologias qualitativas na sociologia. $5^{\mathrm{a}}$ ed. Petrópolis: Vozes, 1997.

KOWARICK, Lúcio. A Espoliação urbana. Rio de Janeiro: Paz e Terra, 1979.

LE CORBUSIER. Urbanismo. São Paulo: Martins Fontes, 1992.

LE GOFF, Jacques. Por amor às cidades: conversações com Jean Lebrun. São Paulo: UNESP, 1998.

LEI N 10.233 de 5 de Junho de 2001.Disponibilidade: <http:/ / www.planalto.gov.br>

MELO, N. J. de A. Barracas da beira da maré: relações de lugar e de visibilidade na cidade do Recife. Recife. Ciências Sociais [Monografia (graduação)]. Universidade Federal de Pernambuco, 2004.

. Não contavam com a minha astúcia - ensaio sobre uma experiência de cidade. Recife. Antropologia [Dissertação (mestrado)]. Universidade Federal de Pernambuco, 2007.

MELO, João Cabral de melo. Morte e vida Severina e outros poemas para vozes. $4^{\mathrm{a}}$ ed. Rio de Janeiro: Nova Fronteira, 2000.

MUMFORD, Lewis. A Cidade na história: suas origens, transformações e perspectivas. 4 ed. São Paulo: Martins Fontes, 1998.

OUTTES, Joel. O Recife: gênese do urbanismo 1927-1943. Recife: FUNDAJ/Massangana, 1997.

PIMENTA, A. A cidade N. In: O Imaginário da cidade. Lisboa: Fundação Calouste Gulbekian/ Acarte, 1989.

Latitude, Vol. 2, n¹, pp.26-42, 2008. 
QUEIROZ, Maria Isaura Pereira de. Relatos Orais: do 'indizível' ao 'dizível'. In: VON SIMSON, Olga de Morais. (Org.). Experimentos com Histórias de vida: Itália Brasil. São Paulo: Vértice, Revista dos Tribunais. 1988.

QUINN, Daniel. Além da civilização - a próxima grande aventura da humanidade. São Paulo: Petrópolis, 2001.

RAMOS, Graciliano. Vidas secas. 78 a ed. Rio de Janeiro: Record, 1999.

RIO, João do. A alma encantadora das ruas. Rio de Janeiro: H. Garnier, 1910.

ROLNIK, Raquel. Exclusão territorial e violência: o caso de São Paulo, Brasil. In: FERNANDES, E; VALENÇA, M. (Orgs.). O Brasil urbano. Rio de Janeiro: Mauad, 2004.

SADER, Eder. Quando novos personagens entraram em cena - experiências, falas e lutas dos trabalhadores da Grande São Paulo (1970-1980). Rio de Janeiro: Paz e Terra, 1988.

SAHLINS, Marshall. Ilhas de história. Rio de Janeiro: Zahar, 1999.

SANTOS, Lúcia Leitão. Os movimentos desejantes da cidade: uma investigação sobre processos inconscientes na arquitetura da cidade. Recife: Fundação de Cultura da Cidade do Recife, 1998.

SAYAD, Abdelmalek. A imigração ou os paradoxos da alteridade. São Paulo: Edusp, 1998.

TUAN, Yi-fu. Topofilia: um estudo da percepção, atitudes e valores do meio ambiente. São Paulo: Difel, 1980.

. Espaço e lugar: a perspectiva da experiência. São Paulo: Difel, 1983.

Latitude, Vol. 2, n¹, pp.26-42, 2008. 